\title{
WHAT MADE THE CAPTAIN'S FAITH SO GREAT?
}

\author{
By A. L. VAIL.
}

The Lord had been active in His ministry for comparatively a long time when $\mathrm{He}$ met the centurian whose faith greatly pleased Him. So was He impressed by it that He spoke of it in an extraordinary way. He said that $\mathrm{He}$ had not found so great faith in Israel, that the faith of this Roman officer was greater than He had met among His own people. This was after He had appointed apostles, spoken many great things, and wrought many wonders of various kinds. 'The significance in this event arose not from the healing in itself, but from the faith of the man for whom it had been done. But when we look for the explanation of the Lord's appreciation of this faith we fail to find it in what the Scripture says about it. We are induced to think that something has been omitted from the story, which something is the thing which supports and explains the encomium spoken by Jesus. So we find for ourselves a problem just here, making it necessary to search for explanation in order to understand the meaning of the applauded faith. Can we find anything to clear the cloud on our understanding?

If we are to discover the meaning not expressed in the record, it seems to me to lie under the surface of Matthew $8: 9$ and Luke $7: 8$ : "For I am a man set under authority, having under me soldiers" who obey my orders. This word "for" indicates an explanation of the great faith, but it is followed by the speaker's statement that he himself is under authority. But what has his being under authority to do with it, provided only that his subordinates obey his orders? 'The text as it stands involves a palpable non sequitur. It assumes something to follow which does not follow. If he had said, "For I am in authority, not under it, and my soldiers obey me", the connection would be consistent. It would mean the captain's recognition 
of the Healer's control of disease as the officer had control of his soldiers; and therefore in the Healer's relation to the disease, as in the officer's relation to his men, all that was necessary was to issue the order. But he did not say that. He said not that he was in authority, superior to his soldiers, but under it, himself a subordinate; and then he proceeded to say that which would naturally have followed the preceding if it had been just the opposite from what it was! How can this incongruity in the connection be removed?

A suggestion may help us if we give it due weight. The account as it stands until the Lord's expression of His estimate of the faith. does not impress us so much with the greatness of the faith, or anything else, as it impresses us with the courtesy, the modesty, the humility of the men's protest against the Healer's giving him the honor which He seemed about to give by entering his house. This is the conspicuous thing on the surface, but Jesus seems to have no appreciation of it, gives it no attention at all; which is the more impressive because this modest and humble gentleman was a military officer of Rome, one of a class whose duty and training were all in the direction of pride and self-assertion. Now, with our perplexity reinforced by this suggestion, let us return to our question, What was it in the centurian's faith that so impressed the Lord with its greatness?

Nothing new was in the healing itself, for such work had been done by .Jesus previously, and presumably many times. One conspicuous example at least seems to have been earlier, as recorded in three Gospels, that of the healing and pardon of the man let down through the roof, the fame of which ran far and almost certainly reached this officer, for it was in Capernaum where he lived. In that instance the four who bore the invalid showed great faith, which moved the Lord toward response, and the crowning favor for that paralytic, the forgiveness of his sin, must have been in response to his own perhaps un- 
spoken faith and penitence, which Jesus recognized without dependence on his dumb tongue. (The four were not thinking of pardon, but healing, the man was thinking of of his sin, his tongue perhaps was paralyzed, but Jesus saw his thought and answered it, in the order in which he saw it, pardon first and healing second.)

Was anything new or superior in the faith that Jesus conld or would heal without the presence of the invalid? According to a commonly accepted harmony, such work had been done in the healing of the nobleman's son, which was not only earlier but also in Capernaum, and was done for a man who was urging the Healer to hasten to his house, quite evidently because he had no idea that the healing could be accomplished at a distance. So the faith in absent treatment indicates no superiority in it.

Was anything in this officer's knowledge of Jesus otherwise, or his religious standing and maturity, indicating greater faith? Nothing seems to appear. On the contrary, that he had built a synagogue indicates his special intimacy with Jewish religion. His friends, who first presented his need to the Lord, said that he not only had provided the synagogue but that he loved their nation. His expenditure for the accommodation of their religion seems to have been promoted by his love for the Jews themselves. That this love expressed itself in a provision for their religion suggests that he loved their re ligion; otherwise he would presumably have provided some other kind of building. It seems easy to believe that he was a proselyte. substantially if not formally, to the religion which he thus favored. This might have been secretly because of his connection with the Roman army. And the more Jewish we understand him to have been, the more are we led to think of him as advanced in knowledge of Jesus and faith in Him, such as would have deprived his faith in this incident of any distinctive element on the basis of which the Isord could have proclaimed it as "greater". 
Now what remains conceivable as a basis for the Master's estimate of this man's faith in this affair as being greater than that of any. Jew in relation to any of the many works which had been done in all of His gracious manifestations to Israel? This question seems to me to bring us to the hrink of a precipice where we must halt in confusion or plunge into an abyss of unreason or bridge the chasm by finding something more in his faith than we have so far found, and this is our quest. Jesus said this extraordinary thing out of His ample knowledge and superior insight. He "knew what was in man", and He knew what was in this man; and if we could see under the surface here as He saw, the presumption is reasonable that we would see what lies there, unexpressed in the text but open to the Lord's eye, which justifies this otherwise perplexing statement.

Consider another step specifically. In what aspect of faith was Jesus speaking here? He repeatedly affirmed and often emphasized the importance, the necessity, of faith considered practically, in relation to securing results of various kinds: sometimes positively when successful and other times negatively when unsuccessful. But here and now faith is considered comparatively, the comparison being between smaller and greater. Such comparative instances elsewhere in the Gospels always compare between two states in the same individual or group. This appears to be the only such comparison in the Gospels between two distinctly differing classes; one Gentile, Roman. military officer; the other the whole Jewish nation in all the ranks of its people flocking to Jesus from all directions.

As we contemplate this man he grows upon us. He is not a blind beggar by the wayside. His precise courtesy, his unadorned modesty, his unfeigned humility, predispose us to think of him as a person superior in character as .Jesus understood character, resting on substantial intelligence and spiritual superiority; as one who be- 
neath his military uniform carried the intellect of a philosopher and the spirit of a saint. Let us not unrein our optimistic imagination here, of course, neither let us trample on it. We are invited, if not commanded, to recognize in him one who thought beneath and above the common currents of religious thinking in his time and environment. whether in Hebrew peasant or Roman commander; one to whom God had spoken beneath the trappings of his employment and the sight of his associates. Did not Jesus, looking into the depths of him, see with what thought he filled the hiatus in the story, and answer that in him when He spoke of his faith? If this is in the direction of a discreet interpretation, what was that conception which had been attained by this modest, courteous and humble man? Keeping in mind our exclusion of greatness in effects, let us look for greatness in character, in philosophy of life or understanding of the great Teacher himself.

Insert the probe beneath the surface in this way: Immediately after the clause, "For I am a man placed under authority", insert these words, "To which authority I am obedient": and then continue, "having soldiers under me'. sc. This is to say that the unrecorded thought of the speaker, which was the source of his current remarks, was that his control of his subordinates depended on his own obedience to his superiors. (Whether his unrecorded thought was also not expressed at that time is immaterial.) Next, let us expand this suggestion in a paraphrase, completing the captain's statement as we assume that Jesus saw it in his mind, and as it stands in our addition to the text, in this way: "Do not trouble yourself to come into my house. I am not worthy and it is not necessary. I think of your authority as it is illustrated by my.own. T am under authority, placed subordinate to $\mathrm{my}$ superiors and supreme over my inferiors in rank. I see myself as a link in a chain of authorities. If my link fails the chain is broken. I keep my mastery 
downward by keeping my loyalty upward. If I disobey the command of my superior, my inferiors are thereby released from their obedience to me. As long as my connections upward are intact my authority downward is such that I do not need to carry my command in person but it is perfectly effective when I send it from anywhere that I may be. So I see You, a mighty prophet of God endowed with authority over all diseases, being empowered from above for the control of them, because You are true to Him who sent You. Your teachings, your works, your character of purity in yourself and graciousness toward the lowly, unite to certify You to this high relationship. Therefore You do not need to go to any place, do not need to speak any audible words. You can heal my servant by Your unspoken command shot silently through the air. Will it, and Your will works it, because the will of God it is Your will to do".

If Jesus saw some such thinking in the captain's mind, as the ground of his confidence in the result through the simplest and swiftest and easiest process. would not that philosophy underlying the faith make it greater than any other that had been utilized and appreciated and applauded by the Lord? Other faiths had been apparently as great on other grounds, but all of them had had only the same comparatively shallow grounds; but here now is faith rooting in deeper grounds and rising to higher realms; the depths and heights of a philosophy of the divine operation and the loftier meanings of the magnificent Healer himselt.

Every faith has its underlying philosophy, or theology, which sustains it and and labels it with the stamp of its grade, its greatness. The ordinary observer, or exerciser, of the faith may not see its philosophy or theology, but the extraordinary observer or exerciser may see it, and his sight will automatically enlarge and exalt his understanding and appreciation of the faith itself. So then, if the Lord here for the first time met an applicant for 
His healing aid who had attained to that conception of His personality and relations upward, which Jesus Himself already had, in that conception may be fairly found the Lord's meaning when He said, "I have not found so great faith in Israel". (This conception of these relationships in this application of it, does not appear to have been previously announced even by Jesus Himself.)

Moreover, notice how Matthew inserts into the body of his report of this incident a few words of the Lord which show that His own thought was then set to a larger view, harmoniously with the centurion's larger view though surpassing it. This larger view of the Master is recorded in immediate connection with His announcement of the greater faith. This announcement was addressed not to the captain, nor privately to apostles or disciples; but the Lord "turned" in order that the announcement might be heard by the "multitude that followed Him", to whom it was addressed. The way that it comes into the record seems to me to indicate a special relation between what Jesus saw in the man's mind and what was in His own mind as $\mathrm{He}$ contemplated the higher meanings and greater conquests of His message in the world. What is it" "I say to you that many shall come from the east and the west, and shall sit down with Abraham and Isaac and Jacob in the Kingdom of Heaven; but the sons of the kingdom (of Israel) shall be cast forth into the outer darkness". This Roman officer almost certainly had no idea of the deity of Jesus as we understand it. He saw in Him only a great prophet of the God of Israel, from Whom He had received extraordinary powers, being endowed exceptionally in consequence of His firm and fine loyalty to God, based in His exalted fellowship with God, as the centurian had come to believe in God. On that basis his superior mind had reasoned along the way between canse and consequence toward the higher conception and the broader application of the same kind of cause and consequence which was in the mind of Jesus. So these 
two were joined and the thought of the one was caught up by the Other as He exclaimed, "I have not found so great faith, not even in Israel"! Consider also in this connection that this seems to have been the first time that our Lord ever expressed to men His own expectation of the extension of His Kingdom to take in people of all races. He had a few times appeared to hint it, had said what might suggest it to those competent to understand, if any such were present, but never before had He spoken it out in full as $\mathrm{He}$ did now, and to an unlimited audience as if He was moved by an enthusiastic optimism in the contemplation of His greater vision of something that had some connection with this man's greater faith. If the conclusion to which this study has now come is accepted, it enhances in a significant way our understanding of these two men.

First and chiefly, it suggests something worth while concerning the development of the Lord's understanding of His mission to earth. Possibly it was what might be termed a climatic resting place of it. To get more precisely, if not more clearly, my meaning in this term, it is necessary to push the prospect a stage further. The next item in the record, and which appears only in Luke's Gospel, is the restoration to life of the youth at Nain. That event exhibits points of progress in the Saviour's benefactions in several ways. It was the first raising of the dead on record in the Gospels, perhaps the first service that was not asked by any one, perhaps the first in connection with which no human faith was required or furnished, and no expectation of the blessing by the recipients of it. Observe these points and meditate on them. Combined they indicate a topmost output of wonderful grace with no condition or source except the "compassion" of the Helper. In the usually recognized chronological order these two, the "so great faith" and the Lord's greatest control over the forces of life and death, stand in recognized conjunction, with nothing whatever between them. Recall not only that Luke alone tells this 
restoration story, but also that he alone pledges himself at the beginning of his Gospel to set the things, of which others had written, in their order. Whatever other kind of order may have been in his mind when he wrote that pledge, the first natural understanding is that he meant the chronological order. Now, having reached this point as we have, the conclusion does not seem chimerical that a close relation exists between what Jesus saw in the centurion's mind and what $\mathrm{He}$ did at Nain as a revelation of His own mind. (The reminder may not be amiss that the word "marveled", as expressing the effect of the captain's faith, means in the original and in various applications generally, "admired", and is so rendered in some translations at this point. Jesus admired the faith that He pronounced "so great".) Out of all this arises the reverent interpretation of Jesus as He approached Nain as being in a new, or at least in a refreshed and strengthened purpose to work on the basis of His compassion alone, or conspicuously, a work at the apex of controlling power; in a field in which Elijah and Elisha had been the only workers among the mighty ancients, and surpassing them in the one motive mentioned, compassion. Those two forerunners in this field had wrought in response to favors shown them by their beneficiaries, and in response to their appeals ; but Jesus now lifts the whole manifestation of helpfulness to a higher plane and a finer function.

Second, contingent on the foregoing and concurrently with it, the centurion rises into significance. $\mathrm{He}$ is disclosed more and more clearly and impressively as a captain, not only in the army of Rome but also in the army of believers in Jesus. Does he not in some sense and some degree appear as the forerunner of that other Gentile, of the same military rank and similar spiritual character, whom Peter met at Caesarea as his Lord had met this one at Capernaum? What the Lord here said to the multitude, concerning the ultimate sweep of His gospel on earth, links itself in its total substance with what Peter learned and what God did through Peter and Cornelius. 